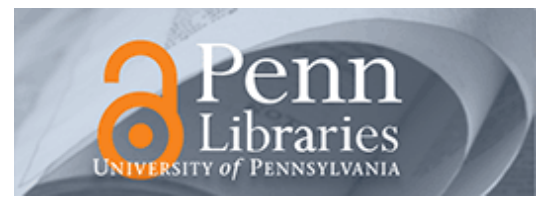

University of Pennsylvania

ScholarlyCommons

September 2005

\title{
Collateral Damage: American Science and the War on Terrorism
}

\author{
Kenneth R. Foster \\ University of Pennsylvania, kfoster@seas.upenn.edu \\ Irving A. Lerch \\ American Physical Society
}

Follow this and additional works at: https://repository.upenn.edu/be_papers

\section{Recommended Citation}

Foster, K. R., \& Lerch, I. A. (2005). Collateral Damage: American Science and the War on Terrorism.

Retrieved from https://repository.upenn.edu/be_papers/60

Copyright 2005 IEEE. Reprinted from IEEE Technology and Society Magazine, Volume 24, Issue 3, Fall 2005, pages 45-52.

This material is posted here with permission of the IEEE. Such permission of the IEEE does not in any way imply IEEE endorsement of any of the University of Pennsylvania's products or services. Internal or personal use of this material is permitted. However, permission to reprint/republish this material for advertising or promotional purposes or for creating new collective works for resale or redistribution must be obtained from the IEEE by writing to pubs-permissions@ieee.org. By choosing to view this document, you agree to all provisions of the copyright laws protecting it.

This paper is posted at ScholarlyCommons. https://repository.upenn.edu/be_papers/60

For more information, please contact repository@pobox.upenn.edu. 


\title{
Collateral Damage: American Science and the War on Terrorism
}

\begin{abstract}
In the wake of the terrorist attacks of 2001, the United States government undertook a rushed effort to increase security. In addition to new legislation such as the Patriot Act and the Homeland Security Act of 2002 , the government dramatically ramped up enforcement of laws that have long been on the books, and revised its policies to deal with new terrorist threats.

While the need for increased security is undeniable, the costs of security measures need to be weighed as well, in terms of collateral damage they produce to the U.S. science and engineering (S\&E) enterprise. That was the message of a panel discussion held at the June 2004 IEEE-SSIT International Symposium on Technology and Society (ISTAS'04) in Worcester, MA [1]. We focus here on two main problems: the increasing difficulties faced by students and scientists from abroad in obtaining visas to visit and study in the United States, and the barriers that are being erected to communication and collaboration between U.S. investigators and international scholars.

\section{Comments}

Copyright 2005 IEEE. Reprinted from IEEE Technology and Society Magazine, Volume 24, Issue 3, Fall 2005, pages 45-52.

This material is posted here with permission of the IEEE. Such permission of the IEEE does not in any way imply IEEE endorsement of any of the University of Pennsylvania's products or services. Internal or personal use of this material is permitted. However, permission to reprint/republish this material for advertising or promotional purposes or for creating new collective works for resale or redistribution must be obtained from the IEEE by writing to pubs-permissions@ieee.org. By choosing to view this document, you agree to all provisions of the copyright laws protecting it.
\end{abstract}




\title{
Collateral Damage: American Science and the War on Terrorism
}

\author{
KENNETH R. FOSTER AND IRVING A. LERCH
}

“... the dependence of U.S. science on foreign scientists is such that biodefense research will be inhibited if we continue down a road of scientific isolationism. Apart from the obvious barriers that restrictions on access to scientific information and tools place on research, restrictions on scientific training for foreign nationals will delay those countries from developing expertise crucial to identifying and containing disease outbreaks - key to any global strategy against bioterrorism. What is required is the proliferation of scientific training worldwide, not scientific isolationism."

Thomas May [1]

T n the wake of the terrorist attacks of 2001, the United States government undertook a rushed effort to increase Csecurity. In addition to new legislation such as the Patriot Act and the Homeland Security Act of 2002, the government dramatically ramped up enforcement of laws that have long been on the books, and revised its policies to deal with new terrorist threats.

While the need for increased security is undeniable, the costs of security measures need to be weighed as well, in terms of collateral damage they produce to the U.S. science and engineering (S\&E) enterprise. That was the message of a panel discussion held at the June 2004 IEEE-SSIT International Symposium on Technology and Society (ISTAS 04) in Worcester, MA [1]. We focus here on two main problems: the increasing difficulties faced by students and scientists from abroad in obtaining visas to visit and study in the United States, and the barriers that are being erected to communication and collaboration between U.S. investigators and international scholars.

\section{"Flattening" of the Worlds of Science and Engineering}

The effect of these changes must be understood in the context of the long-term changes in the productivity of U.S. science vis-à-vis that in the rest of the world, and America's increasing reliance on scientists and engineers from abroad. As World War II drew to an end, Americans might have been forgiven for a mistaken impression that science began and ended in the U.S. At that time,

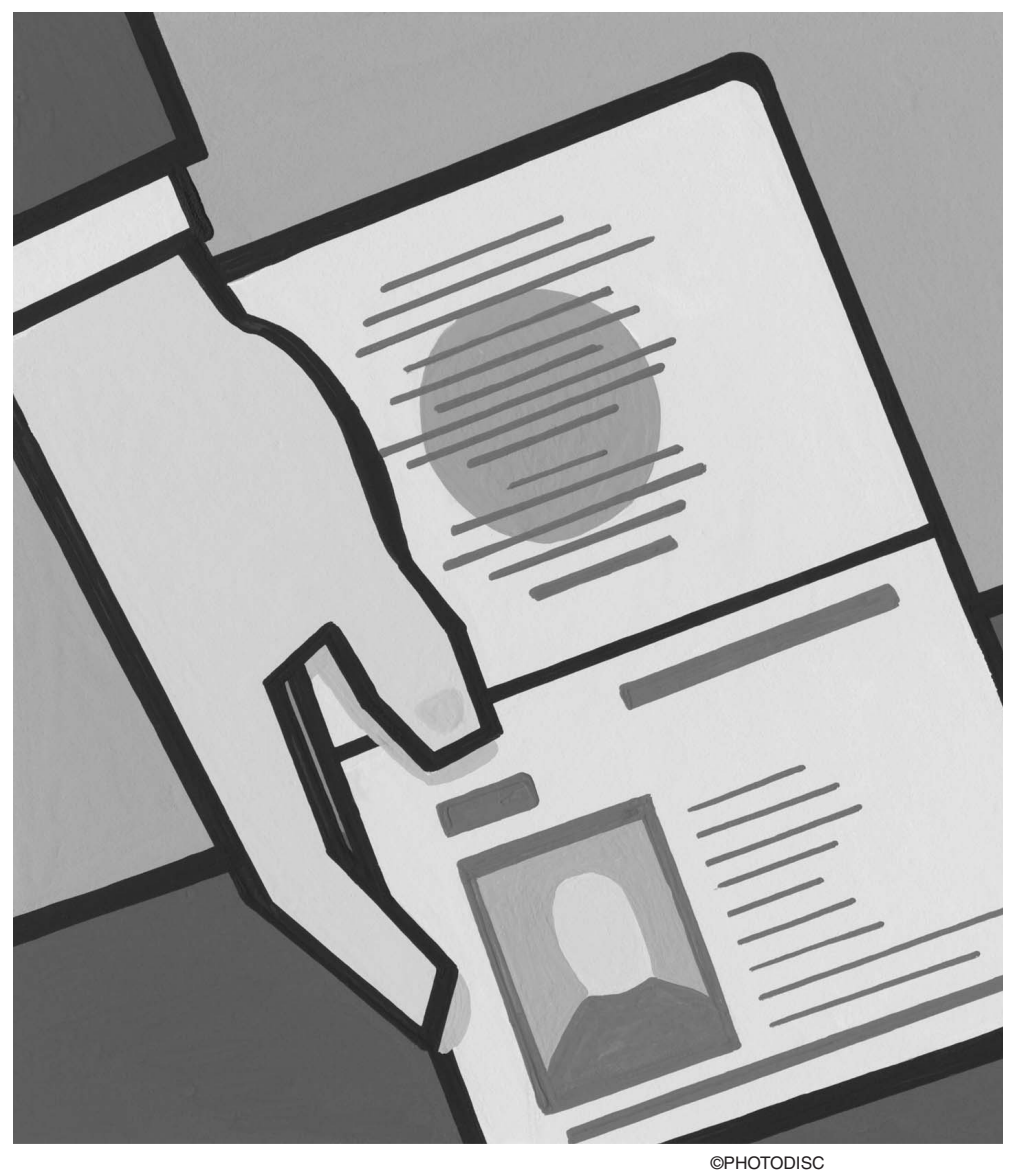

the United States generated by far the largest fraction of the world's S\&E literature, and was the sole proprietor of advanced technologies with important "dual use" (military and civilian) applications.

The changing productivity of U.S. S\&E enterprise vis-à-vis the rest of the world can be seen clearly in the bi-annual Science and Technology Indicators, published by the National Science Board [2]. Figs. 1 and 2 show the numbers of papers published in the standard science and engineering literature by U.S. authors, compared to those by their 
Thousands

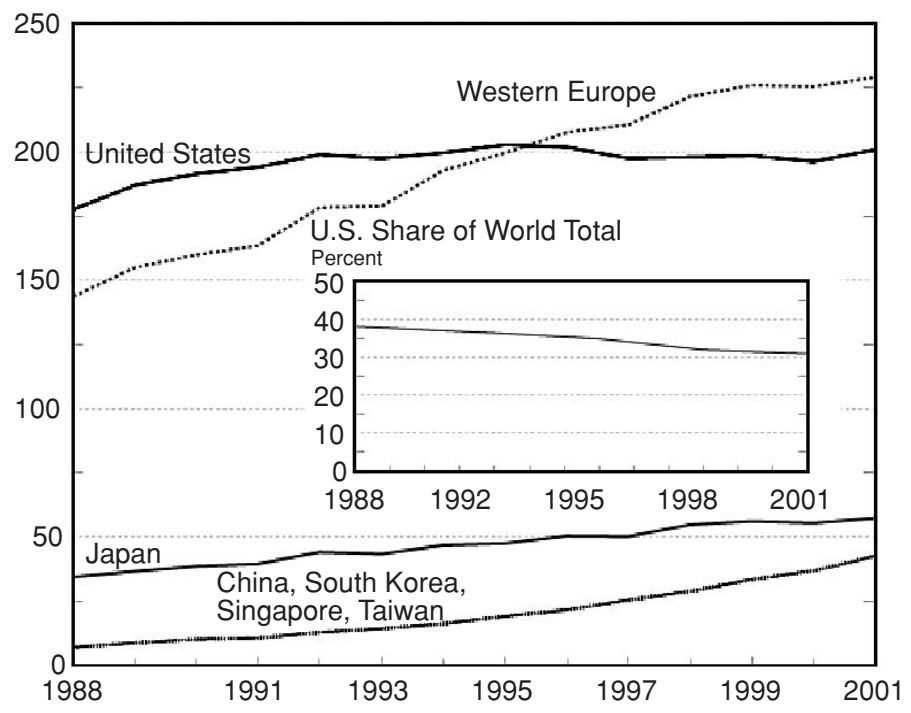

Fig. 1. S\&E articles, by selected country/region and U.S. share of world total: 1988-2001 (source: [2]).

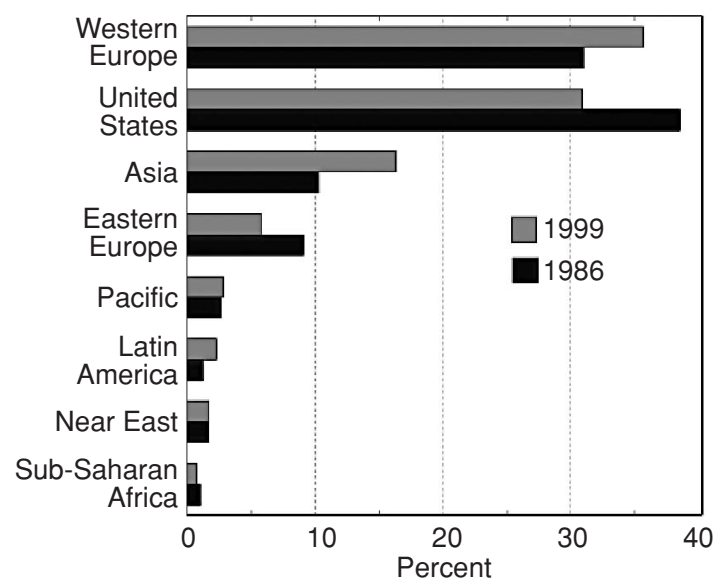

Fig. 2. Scientific publications: regional share of world output (source: [2]).

peers in other countries.

In terms of numbers of papers, the productivity of the U.S. S\&E community has remained essentially flat for the past decade, whereas that of Western Europe, Japan, and other Asian countries has increased substantially. In 1945, U.S. scientists and engineers published about $80 \%$ of the world's S\&E literature; they now account for less than one-third of the world's scientific papers.

A second major trend has been the increasing reliance of the United States on professionals and students from abroad to fill its ranks of engineers and scientists. Since the early 1980s, the number of U.S. white males earning doctoral degrees each year in science and engineering has been declining (Fig. 3). (Tragically, similar declines are seen in the numbers of doctoral degrees earned by white female and U.S. minorities as well). Until 2001, these declines were offset by increases in degrees earned by students holding temporary visas. Now, for reasons that we discuss in the following section, these numbers are in drastic decline.
In Europe and Asia, by comparison, the numbers of people earning doctoral degrees in S\&E have rapidly increased (Fig. 4) and now each region surpasses the U.S. in production of doctoral-level scientists and engineers.

This long-term decline in the United States vis-à-vis other developed countries in its science and engineering productivity does not reflect a decline in absolute terms. The U.S. still has roughly $30 \%$ of the world's share in S\&E productivity, far surpassing that of any other individual nation. The changes reflect, rather, the huge government and private-sector investments by other countries, and concomitant declines in U.S. investment in science and technology vis-à-vis the rest of the world.

It means, however, that any monopoly the U.S. might once have had on science and technology around the world has evaporated, and that the U.S. now depends on scientific ideas and manpower that originate outside its borders. In highenergy physics and materials research, for example, major research facilities have been established in Europe and Asia. This has caused the focus of research on some topics to shift to those regions from the United States. It also means that European and Asian firms now have the option of investing in new research facilities outside the U.S., where they will find a ready supply of highly educated technical personnel and vibrant research programs. Columnist Thomas L. Friedman has called this process the "flattening" of the world [3], and it is clearly taking place in science and technology as well as in other economic activities.

\section{In the Wake of 9/11}

In response to the terrorist attacks of September 11, 2001, the U.S. government passed three major new laws in 2002 (The Enhanced Border Security and Visa Entry Reform Act, the Patriot Act and the Homeland Security Act), and administratively ramped up 
the enforcement of existing laws. This has led to a morass of problems for the U.S. S\&E enterprise.

Two major initiatives, the Visas Mantis and Visas Condor directives, deserve special mention. Visas Condor, which started in January 2002, checks the name of a visa applicant against U.S. government databases to identify terrorists. It primarily affects Muslim men between ages 16 and 45, from 26 predominantly Muslim countries.

The Visas Mantis system, established by the State Department in 1998 , is designed to prevent the entry of persons who might attempt to export sensitive technology illegally from the United States. The program was initially intended to stem the proliferation of weapons of mass destruction. It was applied to visitors from countries designated by the U.S. as State Sponsors of Terrorism, and to nationals of countries designated as "sensitive." Under Visas Mantis, visa applications of scientists are sent to Washington for a check against a "technology alert list" (TAL) of dual-use technologies.

The TAL initially included munitions, nuclear, and rocket technologies and other technologies obviously of use for weapons development. Its scope has expanded since the Sept. 11 terrorist attacks and now includes: chemical, biotechnology, and biomedical engineering, remote sensing, advanced computer technologies, materials technology, cryptography, lasers and directed energy systems, acoustic and sensors technologies, marine technology, robotics, ceramics, and high performance metals and alloys. Even urban planning and architecture are mentioned in the list.

The result has been a dramatic increase in the numbers of visa applications from foreign scientists that are being sent to Washington for security clearance - from 1000 in 2000 to 20000 in 2003. Many visa applicants will trigger a Visas Mantis review even though their work poses no security threat to the U.S.

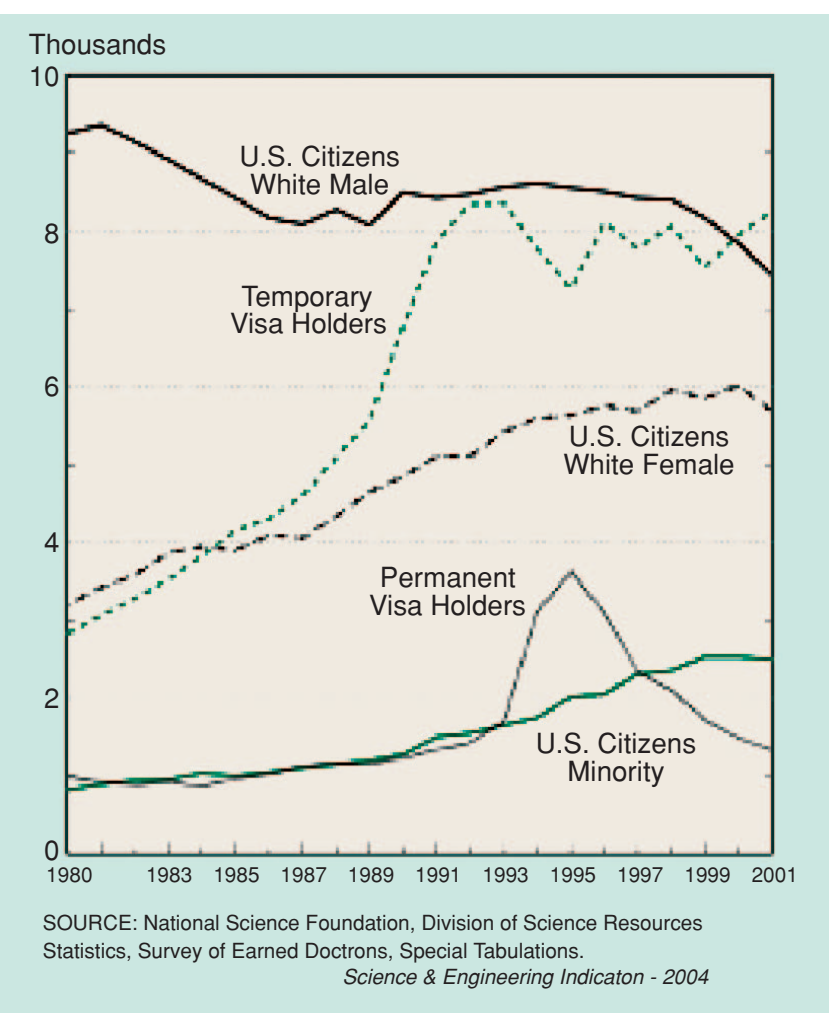

Fig. 3. S\&E Doctorates earned by U.S. citizens and noncitizens: 1980-2001 (source: [2]).

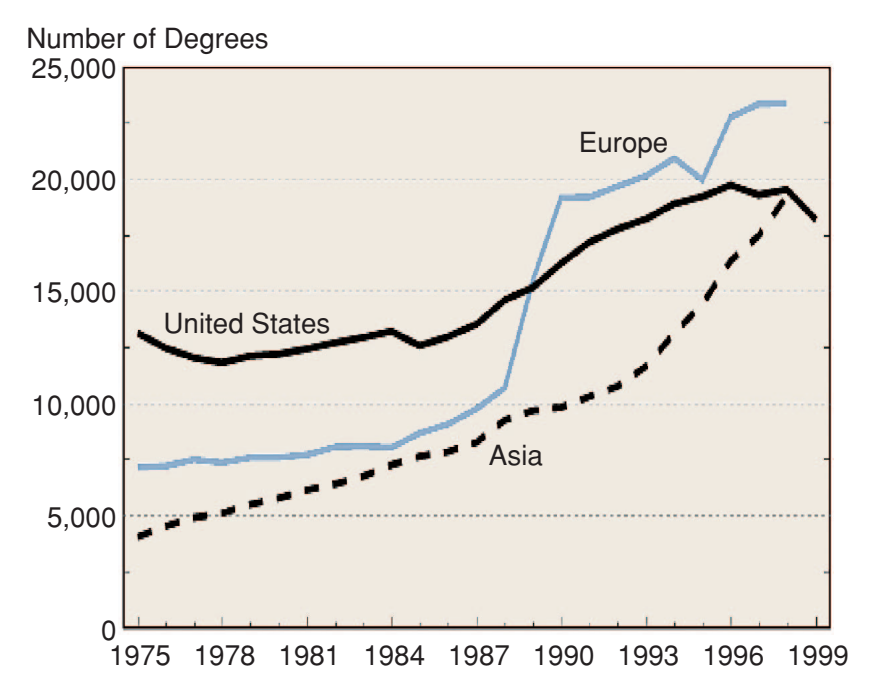

NOTE: Europe includes France, Germany, and the United Kingdom. Asia includes China, India, Japan, South Korea and Taiwan.

Fig. 4. Natural science and engineering doctoral degrees (source: [2]).

Three complications have contributed to the difficulty encountered by many foreign scientists and students in obtaining visas. The first is simply the high caseload of consular officers who, in some European and
Asian consulates, must screen as many as 200 applicants in just a few hours. The waiting time for interviews can in some cases be extended by many months

Second, the legislation that created 
the Department of Homeland Security (DHS) took "visa policy" away from the State Department but retained the consular officer corps to make day-today decisions about issuing visas. The officials who issue visas, who typically are junior members of the foreign service, are unable at times to access computer records maintained at DHS or obtain quick answers to questions about visa policy.

Third, and most important, consular officials have few incentives, and very powerful disincentives, to hurry the process along. In a change made by the U.S. Congress after the 1993 attacks on the World Trade Center, consular officials may be subject to criminal penalties if they grant a visa to a person who subsequently commits a terrorist act in the United States. While these sanctions apply only if a consular official is found to have acted in willful disregard of the law, no official would want to be put in the position of having to raise such a defense. Even minor problems with an applicant's paperwork, or uncertainty on the part of the official whether an applicant needs to be screened for security, can lead to denial or lengthy delays in processing a visa application. Anyone who has ever filled out a government form, or filed income taxes, knows how easy it is to make a mistake, and so the change in law itself means that many well-deserving scientists and students will be denied entry.

The wholly predictable result has been that the number of visas issued to students and scientists has declined precipitously in recent years. Prior to the September 11 attacks, the number of applicants for student (F1) visas steadily increased, but an increasing number of these applicants were rejected as well, leaving the numbers of student visas issued each year relatively steady. Immediately after the 9/11 attacks, the U.S. government dramatically decreased the number of student $(\mathrm{F})$ and exchange (J) visas it issued. Other visa categories decreased as well.

Students and scholars from the People's Republic of China have found it particularly difficult to obtain visas. In a 2002 survey by the American Institute of Physics ${ }^{1}$ of 291 students who had accepted an offer of admission by a physics department of an American universi-

Table I

Trends in International Graduate Applications: 2003-2004 and 2004-2005

\begin{tabular}{l|c|c}
\hline & $\begin{array}{c}\text { Application Changes } \\
\mathbf{2 0 0 3 - 2 0 0 4}\end{array}$ & $\begin{array}{c}\text { Application Change } \\
\mathbf{2 0 0 4 - 2 0 0 5}\end{array}$ \\
\hline $\begin{array}{l}\text { US Domestic and Permanent } \\
\text { Resident }\end{array}$ & $0 \%$ & $-1 \%$ \\
International & $-28 \%$ & $-5 \%$ \\
Country of Origin & $-45 \%$ & $-13 \%$ \\
China & $-28 \%$ & $-9 \%$ \\
India & $-14 \%$ & $0 \%$ \\
Korea & $+4 \%$ & $+6 \%$ \\
Middle East & & \\
Field of Study & $-24 \%$ & $-8 \%$ \\
Business & $-21 \%$ & $-3 \%$ \\
Education & $-36 \%$ & $-7 \%$ \\
Engineering & $-17 \%$ & $+2 \%$ \\
Humanities & $-24 \%$ & $-1 \%$ \\
Life Sciences & $-22 \%$ & $-3 \%$ \\
Physical Sciences & $-20 \%$ & $-4 \%$ \\
Social Sciences & & \\
\hline
\end{tabular}

Source: [14] ty, 100 students were denied visas. Other students, admitted for study to the United States, have suffered long delays in being readmitted to the U.S. after leaving the country briefly for family reasons. Aside from security reviews, a particularly onerous burden on students from poorer nations is the so-called $214 \mathrm{~b}$ requirement that students must prove their intention to return to their country upon completion of studies. In view of the fact that fully $80 \%$ of Chinese students remained in the U.S. in the decades of the 1980s and 1990s, this has been problematic at best.

These requirements have created great hardships to many students. One of us (Lerch) has personally intervened in more than 200 visa cases, most of them concerning scientists or students who were lawfully working or studying in the U.S., who left the country for various reasons and were denied re-entry. Examples include a married Chinese student couple in the U.S. who returned to China following the death of his parents in an accident, and a Russian woman who had worked for 11 years in the U.S. Department of Energy's Ames Laboratory, who went to Germany on family business and was not allowed to return [5]. One of our undergraduates recently had trouble re-entering the country because of security concerns triggered by her major (bioengineering and finance), which shows the lack of specificity of the Technology Alert List.

In part as a result of difficulties in obtaining visas, there has been a major shift in the number and national background of international S\&E students in the U.S. A recent (2005) survey by the Council of Graduate Schools (CGS) reported a $5 \%$ decline in the number of international graduate applications to U.S. universities between 2004 and 2005 (Table I). This continues a decline in first-time graduate enrollments every year since 2001. A

\footnotetext{
${ }^{1}$ Survey conducted by [4].
} 
2004 survey by the Association of American Universities (AAU) [6] reported that 51 out of $52 \mathrm{AAU}$ members experienced a decline in graduate applications, and a majority of AAU members reported declines in new international student enrollment. Smaller effects were found at the undergraduate level, with $46 \%$ of AAU respondents reporting a decrease in international student enrollment while $33 \%$ reported an increase.

Scientists from overseas have commonly faced difficulties in obtaining visas to attend conferences in the United States. In view of lengthy processing times of three months or more, the American Physical Society currently recommends that individuals from "sensitive" countries such as China submit their visa applications six months before a conference date in the U.S. Visa problems were a major factor in the decline of Chinese and Russian participants at the biannual International Symposium in Lepton Photon Interactions (LP). At LP1999 held at Stanford, 12 of 16 invited Chinese citizens and 7 of 25 invited citizens of the former Soviet Union attended. At LP-2003 at Fermi Lab (near Chicago, IL) only one of about 20 invited Chinese and 5 of 20 invited Russians attended. Almost all of Russians who did attend traveled with multi-entry visa or were already in the U.S.

\section{"Sensitive but Unclassified" Information}

Another major impediment to American S\&E enterprise has been the rise of controls on what the government considers to be "sensitive but unclassified" information. The statutory basis for such controls derives from the Export Administration Act and Arms Control Act. This Act regulates "deemed exports"(defined as the release of controlled technology or technical data that conveys information to a foreign entity or individual
Thus, a professor who gives a talk about a controlled technology at an international meeting (or even at a domestic meeting if overseas visitors are present), or merely shows an overseas visitor around the lab, would require a deemed export license. A saving grace, for many university researchers, is the exemption from Export Administration Regulations (EAR) of fundamental research that is intended to be published in the open literature. However, the government's definition of fundamental research is narrowing. According to recent interpretations of government policy, a government-funded project stands to

\section{As WWII drew to an end, Americans might have been forgiven for a mistaken impression that science began and ended in the U.S.}

in the U.S.). The lists of controlled technologies are extensive, and different sets of regulations apply to commercial technology (administered by the Commerce Department) and military technology (administered by the State Department). Violation of export controls can lead to stiff penalties including fines or criminal sanctions. lose its status as "fundamental research" if the sponsor stipulates any restriction on publication or dissemination of the findings of the research, or if the investigator agrees to exclude non-U.S. citizens from meetings with project sponsors. Losing that status would require an investigator to apply for a deemed export license for the research, which might delay a project

Safety First: A Checklist for Researchers

Officials at the University of California and beyond say there are several key steps researchers should take to keep their projects free of deemed-export controls:

- Publish early and often to ensure that your research qualifies as "publicly available."

- Do not accept restrictions on access to or dissemination of information, including informal "handshake" agreements with project managers.

- Do not provide citizenship, nationality, or visa status information to project sponsors or other third parties, or agree to background checks for project participants.

- Do not attend meetings from which foreign nationals are barred.

Source: [13]. 
for months or longer. This has led the University of California at Berkeley to offer guidelines to researchers to keep their research free of deemed export controls (See box).

More rigorous enforcement of deemed export controls is in store for universities. In March 2004, the Inspector General of the Department of Commerce issued a report entitled, "Deemed Export Controls May Not Stop the Transfer of Sensitive Technology to Foreign Nationals in the U.S." [7], and took the position that controls apply to research equipment that has potential dual-uses, whether or not it is being used for fundamental research. The report calls for a new policy that requires a deemed export license for employees or visitors who were born in countries to which used in university research, e.g., high-end computers, oscilloscopes, and fermenters, are included in the controlled list.... Security would have to be implemented to ensure in such cases that non-licensed foreign members of and visitors to the campus will not have access to controlled equipment. This interpretation eviscerates the EAR fundamental research exemption. It will have a chilling effect on university research and education as well as compel discriminatory treatment of foreign nationals on campus."

If these regulations come into effect, the day may soon be at hand

\section{U.S. scientists and engineers now account for less than one-third of the world's scientific papers.}

the export controls apply (China, Cuba, India, Iran, Israel, Libya, North Korea, Pakistan, Russia, Sudan, and Syria), regardless of their present citizenship. In March 2005, the Department of Commerce, Bureau of Industry and Security, published an advanced notice of rulemaking in the Federal Register that would implement those recommendations [8].

The implications for U.S. science are troubling. As Robert Hardy from the Council on Governmental Relations concluded in his November 2004 assessment [9]:

"[T]he most immediate issue is the discussion of the "use" of EAR [Export Administration Regulations] - controlled equipment by foreign nationals at universities and the fundamental research exemption... Many items routinely when students in U.S. universities will have to wear color-coded identification badges, with students born in China, Cuba, India, Iran, Iraq, Israel, Libya, North Korea, Pakistan, Russia, Sudan and Syria (even though they might presently be U.S. citizens) being denied access to particular instruction or research opportunities, depending on the controls that are in effect for their countries of birth. One might assume that plenty of high-end computers, oscilloscopes, and fermenters are found elsewhere in the world, out of reach of U.S. deemed export controls. Overly broad restrictions on access to such equipment by foreign-born scientists in U.S. labs will only damage the country's science without any benefit of improved security.

The effects of controls on "sensitive but unclassified" information are particularly severe for the nation- al laboratories. Even in the three national laboratories that conduct weapons research, the vast majority of research is unclassified and in the public domain. The weapons labs have had many visitors who have conducted scientific and engineering business. All of this has now come to a halt. What will happen to the Brookhaven National Laboratory, for example, which has a billion dollar investment and 10000 users, half of whom are foreign?

\section{Restrictions on Scientific Collaboration and Publication}

A bizarre episode, involving the ability of scientific journals within reach of U.S. law to publish articles from authors in several countries, has recently concluded. This saga began shortly after the Sept. 11 terrorist attacks, when the IEEE, after reviewing U.S. laws regarding trade embargoes, essentially withdrew all member services to members in embargoed countries (including Cuba, North Korea, Iran, until recently Sudan and Libya). The IEEE, unannounced, stopped publishing papers from authors in these countries and in 2002 requested a ruling by the U.S. Department of the Treasury on the matter.

A subsequent series of rulings by the Office of Foreign Assets Control (OFAC) of the Department of the Treasury created confusion and anxiety among scientific and other scholarly societies. In its first ruling (Sept. 2003), OFAC said that journals could publish papers from authors from embargoed countries, but could not "edit" them (or even correct their English) without a license. A later ruling (April 2004) allowed limited editing but forbade "collaborative interactions" between authors in embargoed countries and U.S. scholars that result in co-authorship. Needless to say, many jointly authored papers appear every year (more than 200 in 2003 with U.S. and Iranian coauthors), and the ruling would, obviously, criminalize many American 
scientists. In December 2004, the publication issue came to a happy end. The U.S. Treasury issued a "general license" that allows "U.S. persons to freely engage in most ordinary publishing activities with persons in Cuba, Iran, and Sudan" (and presumably other countries on the embargoed list as well).

The finding by OFAC was a classic case of bureaucratic overreaching, and constituted one of the gravest threats to the integrity of U.S. scientific freedom in decades. OFAC's ruling was taken in response to an inquiry by IEEE. And whereas IEEE chose to accept the OFAC adjudication that obliged publishers to seek government license before publishing such material (a form of prior restraint on publication that is seemingly in tension with the First Amendment), many other scientific publishers ignored the order.

In the face of pending litigation (including a complaint filed by Iranian Nobel Laureate Shirin Ebadi), OFAC reversed its original ruling in December 2004, and granted a "general license" for publications to edit and publish manuscripts submitted by authors from embargoed countries. However, much damage had been done to American science in general and to the IEEE in particular. Prominent European scientists and engineers protested the 2003 OFAC ruling, and more than 5000 members of the IEEE around the world signed a petition protesting that "discrimination on the basis of nationality or country of residence goes against the principles of an international scientific organization." In the aftermath of the Iraq invasion, a number of European scientists called for boycotts on U.S. publications. Had the 2003 OFAC order been enforced by the courts, European and Asian journals would have rushed to replace U.S. journals, creating immediate damage to the U.S. science and engineering publishing enterprise.

However, the issue is not fully resolved. "The AAUP [American
Association of University Professors] welcomes the Treasury Department's recognition that restricting scholarly exchanges does not contribute to international security," says Roger Bowen, general secretary of the organization. "But we still oppose the notion that the federal government has any right to research damage our relationships with allies... Once [scientists] begin to boycott U.S. conferences or avoid sabbaticals in the U.S. due to the difficulties they face or in solidarity with those who face them, the nation will be gravely harmed.

\section{In the wake of the terrorist attacks of 2001, the United States government undertook a rushed effort to increase security.}

regulate the exchange of information between individuals in two countries, even by granting a 'general license.' Congress has spoken on this matter: information and information materials are exempt from trade embargo laws" [10].

\section{Limiting Damage \\ to U.S. S\&E Enterprise}

In a powerful statement in 2003 , M.I.T. Vice President Alice P. Gast [11] described ways in which government controls will damage the U.S. S\&E enterprise:

v "The control of information restricts its dissemination domestically as well as internationally. This undermines our system of peer review, competitive proposal evaluation, and collaboration, and removes the serendipitous discoveries arising from casual access...

- The restrictions of research results discourage young people from pursuing research in heavily regulated fields. If the restrictions and processes to pursue research become too onerous, scientists will migrate to other work...

- Controls on information and international participation in
- Restrictions on the dissemination of research results undermine the close synergy between research and education that make our system great and propel our leadership in innovation...

- When restrictions are not carefully considered and weighed, absurd examples of government controls create an atmosphere of distrust or contempt within a community of researchers....

- Hindering our ability to recruit the best and brightest international students and scholars harms our productivity and leadership in science and technology."

According to Gast, three major needs have to be addressed: improving dialog between government and universities, ensuring openness in research while protecting national security, and developing clear and effective immigration policies.

These problems have hardly escaped the U.S. science and engineering communities, but have been subject to considerable high-level discussion (if not much public outcry by the universities). Particularly urgent is the need to improve the visa process, which presently causes 
unconscionable delays even to wellqualified applicants with a long track record. To be sure, the U.S. government has made efforts to reduce some of the delays. According to a February 2005 statement by the Government Accountability used by the Visas Martis program.

Finding an appropriate balance between openness and security will be a difficult process and one that is subject to bureaucratic over-reaching by the government. The United States has a valid interest in not having its

\section{Any monopoly the U.S. might have once had on science and technology around the world has evaporated, and the U.S. now depends on scientific ideas and manpower that originate outside its borders.}

Office, the present delay for receiving clearance under Visas Mantis has been brought down to about 15 days, from an average of 67 days in 2003; the government has also extended clearances to allow scientists to exit and reenter the U.S. for one year without having to undergo additional Visas Mantis reviews. And at least one senator has proposed legislation to exempt students from the $214 \mathrm{~b}$ requirement (i.e., the requirement to prove that they intend to return to their home countries after their education); the likelihood of passage is remote.

More needs to be done. In a report released in May 2005, the Committee on Science, Engineering, and Public Policy of the National Research Council [12] called for "clear procedures that do not unnecessarily hinder the flow" of international students. The committee recommended a variety of changes, for example, changing visa requirements to allow international students to attend scientific meetings abroad without fear of being denied reentry to the U.S. and extending the duration of Visas Mantis clearances for international students and scholars from all countries. It also recommended that scientists participate in revising - and we hope narrowing - the Technology Alert list science used against it in a terrorist attack. But overly broad restrictions on scientific communication are, if anything, even more damaging to the country. If students, scientists, and firms wishing to start research laboratories cannot find adequate collegial environments in the United States they will simply go elsewhere, and the United States will suffer.

By its immense investments in S\&E over the years and its historically open policies for admitting foreign students, the U.S. has raised the bar for science and engineering and exported both the aspirations for technical excellence and welltrained students to institutions throughout the world. By imposing unnecessary barriers to students of those students seeking to enter the U.S., we stand in danger of cutting off access to the fruits that we ourselves have produced. The U.S. has little to gain by discouraging the globalization of knowledge, since that process is already well along. To return to the quotation by Thomas May at the beginning of this article, we need to encourage the proliferation of scientific training worldwide, not scientific isolationism.

\section{Author Information}

Kenneth R. Foster is with the Department of Bioengineering, University of
Pennsylvania, Philadelphia PA 19104 -6392; email: kfoster@seas.upenn. edu. Irving A. Lerch is the Chair-Elect of the Forum on International Physics, The American Physical Society, and a member of the Board of Trustees of Americans for UNESCO. He works in Washington, DC; email: ialerch@ verizon.net.

\section{Acknowledgment}

The authors thank Wade Robison, from Rochester Institute of Technology, for helpful comments on an earlier draft of this article.

\section{References}

[1] International Symposium on Technology and Society 2004 (ISTAS 04), June 17-19, 2004, Worcester, MA; http://www.wpi.edu/News/ Conf/ISTAS/worcester.html.

[2] NSF National Science Board Science and Engineering Indicators - 2004, National Science Foundation, Washington, DC, 2004; http://www.nsf.gov/sbe/srs/seind04/start.htm/. [3] T. L. Friedman, The World is Flat; A Brief History of the Twenty-First Century. New York, NY: Farrar, Straus and Giroux, 2005.

[4] American Institute of Physics, AIP Report, June 2003; http://www.aip.org/statistics/ trends/reports/international.pdf./

[5] J. Dawson, "Post-September 11th visa woes still plague international students and scientists," Physics Today, June 2003; http://www.physicstoday.org/vol-56/iss-6/p25.html.

[6] Association of American Universities, Washington, DC; http://www.aau.edu/homeland/Survey Results-Int1StudentEnroll/ $\mathrm{PR}=/ \# 10 /-10-2004 . p d f$.

[7] Inspector General, U.S. Department of Commerce, Final Inspection Report No. IPE16176, Mar. 2004,

[8] "Proposed rules," Federal Register, vol. 70, no. 58, Mar. 28, 2005; http://edocket.access.gpo.gov/ 2005/pdf/05-6057.pdf.

[9] R. Hardy, "Export controls and universities: Licensing research?" Council on Governmental Relations, Washington, D.C. , Nov. 10-12, 2004; http://206.151.87.67/docs/NACUA.doc. [10] R. Bowen, "Restrictions on scholarly editing dropped," American Association of University Professors, Mar./Apr. 2005; http://www. findarticles.com/p/articles/mi_qa3860/is_2005 03/ai_n13635316.

[11] A. P. Gast, "The impact of restricting information access on science and technology," M.I.T., Cambridge, MA, 2003; http://www. aau.edu/research/Gast.pdf.

[12] Policy Implications of International Graduate Students and Postdoctoral Scholars in the United States, National Research Council, Washington DC, 2005; http://www.nap.edu/ books/0309096138/html.

[13] "Safety first: A checklist for researchers," The Berkeleyan, Jan. 27, 2005; http://www.berkeley. edu/news/berkeleyan/2005/01/27_acfreedom .shtml.

[14] H. Brown and M. Doulis, "Findings from 2005 CGS International Graduate Admissions Survey," Council of Graduate Schools, Washington, DC; http://www.cgsnet.org/pdf/CGS2005Int1AppRep.pdf. 